\title{
PENGARUH PENYULUHAN MAKANAN JAJANAN DENGAN METODE PERMAINAN ULAR TANGGA TERHADAP PENGETAHUAN ANAK SEKOLAH DI SDN 2 KUTA KABUPATEN LOMBOK TENGAH
}

\author{
Sarianti $\left.^{1}\right)^{*}$, I Nyoman Adiyasa $^{2}$ ), Susilo Wirawan) ${ }^{3}$, dan Yuli Laraeni $^{4}$ ) \\ ${ }^{1}$ Staf Pengajar Jurusan Gizi, Poltekkes Kemenkes Mataram, Indonesia \\ Jl. Praburangkasari Dasan Cermen, Sandubaya Kota Mataram \\ Telp.Fax. (0370) 633837 \\ Email : jurnalgiziprima@gmial.com \\ ${ }^{2}$ Alumni Jurusan Gizi, Poltekkes Kemenkes Mataram, Indonesia \\ Email : antiiisr@gmail.com
}

\begin{tabular}{l}
\hline \hline Article Info \\
\hline Article history: \\
Received Jan $12^{\text {th }}, 201 x$ \\
Revised Feb $20^{\text {th }}, 201 x$ \\
Accepted Mar $26^{\text {th }}, 201 x$ \\
\hline
\end{tabular}

Keyword:

Keywords: Extension of snack foods, snake ladder games, knowledge of school children.

\section{Kata Kunci: \\ Penyuluhan makanan jajana permainan ular tangg pengetahuan anak sekolah.}

\begin{abstract}
Background: Based on the results of basic health research (RISKESDAS) in 2013, in NTB in the age group 10 years and over, having a risky dietary consumption behavior is by consuming sweet foods $32.3 \%$, salty $10.9 \%$, fatty $26.1 \%$, burned $5.6 \%$, animal preserved $4.4 \%$, flavored $84.8 \%$, coffee $37.5 \%$, caffeine besides coffee $4.3 \%$ of their daily needs. Based on data from preliminary studies at SDN 2 Kuta, getting from 43 children as many as 41 children the knowledge of snack foods is in the less category, namely $95.3 \%$ and only 2 children from 43 children who have knowledge of snack foods are in the sufficient category of $4.7 \%$.

Objective: To find out the influence of snack food counseling with the method of snake and ladder games on the knowledge of school children in class $\mathrm{V}$ students.

Method: Using a quasy experimental non equivalent control group, with a sample of 22 people. Collecting knowledge data obtained from questionnaires, data is processed descriptively. Analysis using the independent T-test and paired t-test.

Results: The results of this study indicate that street food counseling using the snake ladder method has a significant influence on the knowledge of school children $(\mathrm{p}$ value $=<0.005)$

Conclusion: Extension of snack foods using the snake ladder method has an influence on the knowledge of school children at SDN 2 Kuta Central Lombok Regency.
\end{abstract}

\footnotetext{
ABSTRAK

Latar Belakang : Berdasarkan data hasil riset kesehatan dasar ( RISKESDAS ) tahun 2013, Di NTB pada kelompok usia 10 tahun ke atas , memiliki perilaku konsumsi makanan beresiko yaitu dengan konsumsi makanan manis $32,3 \%$, asin $10,9 \%$, berlemak $26,1 \%$, di bakar $5,6 \%$, hewani berpengawet $4,4 \%$, penyedap $84,8 \%$, kopi $37,5 \%$, kafein selain kopi $4,3 \%$ dari kebutuhan seharinya. Berdasarkan data hasil studi pendahuluan di SDN 2 Kuta mendapatkan dari 43 anak sebanyak 41 anak pengetahuan tentang makanan jajanan berada dalam kategori kurang yaitu 95,3\% dan hanya 2 anak dari 43 anak yang memiliki pengetahuan tentang makanan jajanan berada dalam kategori cukup yaitu $4,7 \%$.
} 
Tujuan : Mengetahui pengaruh penyuluhan maknan jajanan dengan metode permainan ular tangga terhadap pengetahuan anak sekolah pada siswa kelas $\mathrm{V}$.

Metode : Menggunakan quasy experimental design non equivalent control group, dengan jumlah sampel 22 orang. Pengumpulan data pengetahuan diperoleh dari kuesioner, data diolah secara diskriptif. Analisa menggunakan uji independent T-test dan uji paired t-test.

Hasil : Hasil penelitian ini menunjukkan bahwa penyuluhan makanan jajanan dengan metode permainan ular tangga memiliki pengaruh yang signifikan terhadap pengetahuan anak sekolah $(\mathrm{p}$ value $=<0,005)$

Kesimpulan : Penyuluhan makanan jajanan dengan metode permainan ular tangga memiliki pengaruh terhadap pengetahuan anak sekolah di SDN 2 Kuta Kabupaten Lombok Tengah.

\section{PENDAHULUAN}

Menurut Judarwanto,W (2008), Jajanan yang sehat dan aman adalah makanan jajanan yang memiliki komposisi gizi yang baik dan seimbang serta tidak mengandung pangan berbahaya yang dapat mengganggu, merugikan dan membahayakan kesehatan manusia.

Menurut riskesdas tahun 2013, di indonesia pada kelompok usia 10 tahun ke atas, memiliki perilaku konsumsi makanan beresiko sangat tinggi dengan konsumsi makanan manis 53, 1\%, asin 26,2\%, berlemak $40,7 \%$, di bakar 4,4\%, hewani berpengawet 4,3\%,penyedap 77,3\%, kopi 29,3\%, dan kafein selain kopi 5,6\% dari kebutuhan seharinya. Di NTB pada kelompok usia 10 tahun ke atas, memiliki perilaku konsumsi makanan beresiko yaitu dengan konsumsi makanan manis 32,3\%, asin 10,9\%, berlemak 26,1\%, di bakar $5,6 \%$, hewani berpengawet $4,4 \%$, penyedap $84,8 \%$, kopi $37,5 \%$, kafein selain kopi $4,3 \%$ dari kebutuhan seharinya.

Penelitian yang di lakukan suatu lembaga studi di Jakarta Timur mengungkapkan bahwa jenis jajanan yang sering di konsumsi anak - anak sekolah adalah lontong, otak - otak, tahu goreng, bakso dan es sirup . Berdasarkan uji lab pada otak - otak dan bakso di temukan boraks, tahu goreng di temukan formalin, dan es sirup positif mengandung Rhodamin-b . Penelitian lain yang di lakukan di bogor telah di temukan salmonella paratyphi A di 25\%-50\% sampel minuman yang di jual di kaki lima (Adriani,2012 ).

Makanan jajanan memegang peranan yang cukup penting dalam memberikan asupan energi dan zat gizi lain bagi anak-anak usia sekolah. Konsumsi makanan jajanan anak sekolah perlu diperhatikan karena aktivitas anak yang tinggi. Konsumsi makanan jajanan anak diharapkan dapat memberikan kontribusi energi dan zat gizi lain yang berguna untuk pertumbuhan anak (Sutardji, 2007; Susan, 2010; Guarantor, 2006).

Pengetahuan yang masih rendah menjadi salah satu faktor memilih makanan jajanan (Andriani,2011). Untuk mengurangi paparan anak sekolah terhadap makanan jajanan yang tidak sehat dan tidak aman di konsumsi perlu di lakukan beberapa promosi keamanan pangan cara efektif promosi kesehatan. Sudah banyak upaya upaya yang di lakukan untuk meningkatkan pengetahuan salah satunya dengan melakukan penyuluhan. 


\section{METODE PENELITIAN}

Metode ppenelitian ini Menggunakan quasy experimental design non equivalent control group, analisa pada penelitian ini menggunakan uji independent T-test untuk mengetahui ada tidaknya perbedaan pengeahuan pada kelompok perlakuan dan kelompok kontrol pada saat sebelum (pre-test) dan sesudah di berikan penyuluhan makanan jajanan dengan permainan ular tangga (post-test) dan uji paired $t$-test untuk mengetahui apakah ada pengaruh pemberian penyuluhan makanan jajanan dengan metode permainan ular tangga pada kelompok perlakuan padaa saat pretest dan posttest.

\section{HASIL PENELITIAN}

\section{KARAKTERISTIK SAMPEL}

Hasil penelitian menunjukkan bahwa usia sebagian sampel pada penelitian pada kelompok perlakuan sampel berusia 11 tahun sedangkan pada kelompok kontrol sampel berusia 10 tahun. Pada jenis kelamin sebagian sampel berjenis kelamin laki-laki pada kelompok perlakuan dan kelompok kontrol.

Tabel 1.Karakteristik Responden

\begin{tabular}{|c|c|c|c|c|c|c|}
\hline \multirow[t]{2}{*}{ Umur } & \multicolumn{2}{|c|}{ Perlakuan } & \multicolumn{4}{|c|}{ Kontrol } \\
\hline & $\mathrm{N}$ & $\%$ & & $\mathrm{n}$ & & $\%$ \\
\hline 10 tahun & 3 & 13,6 & & 1 & & 4,8 \\
\hline 11 tahun & 12 & 54,5 & & 10 & & 47,6 \\
\hline 12 tahun & 7 & 31,9 & & 10 & & 47,6 \\
\hline Total & 22 & 100,0 & & 21 & & 100,0 \\
\hline \multirow{2}{*}{\multicolumn{2}{|c|}{ Jenis kelamin }} & \multicolumn{2}{|c|}{ Perlakuan } & & \multicolumn{2}{|c|}{ Kontrol } \\
\hline & & $\mathrm{n}$ & $\%$ & & $\mathrm{~N}$ & $\%$ \\
\hline \multicolumn{2}{|c|}{ Laki - laki } & 15 & 68,2 & & 11 & 52,4 \\
\hline \multicolumn{2}{|c|}{ Perempuan } & 7 & 31,8 & & 10 & 47,6 \\
\hline \multicolumn{2}{|c|}{ Total } & 22 & 100,0 & & 21 & 100,0 \\
\hline
\end{tabular}

Tabel 2. Hasil Pre-test Perlakuan dan Kontrol Menggunakan Uji Manny-whitney

\begin{tabular}{|c|c|c|c|c|c|}
\hline \multirow[t]{3}{*}{$\begin{array}{l}\text { Pre - test perlakuan } \\
\text { dan kontrol }\end{array}$} & Kelompok & $\mathrm{n}$ & $\begin{array}{l}\text { Mean } \\
\text { Ranks }\end{array}$ & $\begin{array}{l}\text { Asymp.sig.(2- } \\
\text { tailed) }\end{array}$ & SD \\
\hline & Perlakuan & 22 & 20,82 & & \\
\hline & Kontrol & 21 & 23,24 & 0,526 & 9,632 \\
\hline \multicolumn{2}{|c|}{ Total } & 43 & & & \\
\hline
\end{tabular}


Tabel 3. Distribusi Hasil Post-test Kelompok Kerlakuan dan Kelompok Kontrol menggunakan Uji Mannywhitney.

\begin{tabular}{|c|c|c|c|c|c|}
\hline $\begin{array}{l}\text { Post-test perlakuan } \\
\text { dan kontrol }\end{array}$ & Kelompok & $\mathrm{n}$ & $\begin{array}{l}\text { Mean } \\
\text { Ranks }\end{array}$ & $\begin{array}{c}\text { Asymp.sig.(2- } \\
\text { tailed) }\end{array}$ & SD \\
\hline & Perlakuan & 22 & 27,16 & \multirow{3}{*}{0.006} & \multirow{3}{*}{9.846} \\
\hline & Kontrol & 21 & 16,60 & & \\
\hline Total & & 43 & & & \\
\hline
\end{tabular}

Tabel 4. Pengaruh Penyuluhan Makanan Jajanan Dengan Metode Permainan Ular Tangga Terhadap Pengetahuan Anak Sekolah di SDN 2 Kuta.

\begin{tabular}{|c|c|c|r|}
\hline Tingkat pengetahuan & $\mathrm{n}$ & Asymp.sig.(2-tailed) & SD \\
\hline Pre - test dan post - test pada kelompok perlakuan & & & 11.395 \\
\cline { 3 - 4 } & 22 & 0.000 & 10.594 \\
\hline
\end{tabular}

Berdasarkan tabel 2 dapat diketahui hasil uji pre-test kelompok perlakuan dan kelompok kontrol menggunakan uji manny-whitney diperoleh nilai mean ranks untuk kelompok perlakuan yaitu 20,82 dan kelompok kontrol nilai mean yaitu 23,24 dengan hasil asymp.sig (2-tailed) yaitu 0,526, jadi dapat dikatakan diantara kelompok perlakuan dan kontrol sebelum diberikan penyuluhan dengan metode permainan ular tangga tidak ada beda rata-rata pengetahuannya.

Berdasarkan tabel 3 dapat diketahui bahwa hasil uji post - test kelompok perlakuan dan kelompok kontrol dengan menggunakan uji manny-whitney diperoleh nilai mean Ranks untuk kelompok perlakuan yaitu 27,16 dan untuk kelompok kontrol nilai mean Ranks yaitu 16,60 dengan hasil asymp.sig.(2-tailed) diperoleh nilai $\mathrm{p}$ value $=0.006(\mathrm{p}<0,05)$, jadi antara kelompok perlakuan dan kontrol setelah diberikan penyuluhan dengan metode permainan ular tangga ada beda pada tingkat pengetahuannya, sehingga dapat dikatakan bahwa ada pengaruh penyuluhan makanan jajanan dengan metode permainan ular tangga terhadap pengetahuan anak sekolah di SDN 2 Kuta.

Berdasarkan tabel 6 dapat diketahui bahwa hasil uji pengaruh penyuluhan makanan jajanan denga metode permainan ular tangga terhadap pengetahuan kelompok perlakuan menggunakan uji Wilcoxon diperoleh niali $\mathrm{p}$ value $=0.000$ atau $\mathrm{p}$ value $=<0,05$, jadi ada pengaruh penyuluhan makanan jajanan dengan metode permainan ular tangga terhadap pengetahun anak sekolah di SDN 2 Kuta.

\section{PEMBAHASAN Pengetahuan}

Berdasarkan hasil penelitian menunjukkan bahwa sebelum (pre-test) di berikan penyuluhan dengan menggunakan metode permainan ular tangga sampel memiliki tingkat pengetahuan baik 6 orang $(27,3 \%)$, cukup 13 orang $(59,1 \%)$, kurang 3 orang $(13,6 \%)$ dan sesudah (post-test) di berikan penyuluhan jumlah sampel dengan tingkat pengetahuan baik 16 orang (72,7\%), cukup 6 orang (27,3\%). Berdasarkan hasil tersebut di katakan bahwa sebagian besar dari responden kelas V SDN 2 Kuta Kabupaten Lombok Tengah berpengetahuan baik dalam memilih makanan jajanan. 
Makanan jajanan yang kurang memenuhi kesehatan dan gizi akan mengancam kesehatan anak usia sekolah. Makanan jajanan berdampak negatif apabila makanan yang di konsumsi tidak mengandung nilai yang cukup dan idak terjamin kebersihan serta keamanannya. Selain menimbulkan masalah gizi, dampak mengkonsumsi makanan yang tidak baik akan mengganggu kesehatan anak seperti terserang penyakit saluran pencernaan dan dapat timbul penyakit - penyakit lainnya yang di akibatkan pencemaran kimiawi. Sehingga hal ini berdampak pada menurunnya konsentrasi belajar siswa, meningkatnya aksensi dapat berpengaruh pada prestasi belajar anak. Selain itu, asupan gizi yang tidak baik akan mempengaruhi pertumbuhan dan perkembangan anak pada usia sekolah yang sangat membutuhkan banyak asupan gizi untuk masa kembangnya (Safriana,2012).

Pengetahuan anak juga di pengaruhi oleh lingkungan, seperti lingkungan pergaulan anak yang memiliki pengetahuan kurang ketika bergaul dengan anak yang memiliki pengetahuan yang baik maka anak tersebut akan cenderung mengikuti dan akhirnya memiliki pengetahuan yang baik juga. Hal ini di sebebkan karena lingkngan merupakan seluruh kondisi yang ada di sekitar manusia dan pengaruhnya yang dapat mempengaruhi perkembangan dan perilaku orang atau kelompok (Wawan A, Dewi,2010).

\section{Pengaruh Penyuluhan Makanan Jajanan Dengan Metode Permainan Ular Tangga Terhadap Pengetahuan Anak Sekolah di SDN 2 KUTA}

Bentuk media ular tangga yang di modifikasi dengan makanan jajanan. Permainan ular tangga Menurut Maisyaroh (2014) permainan ular tangga adalah kegiatan yang menyenangkan hati, di mainkan oleh sekelomok orang dengan menggunakan papan yang di bagi dalam kotak - kotak kecil dan di beberapa kotak di gambar sejumlah " tangga" dan "ular" yang menghubungkan dengan kotak lain.

Penyuluhan menggunakan permainan ular tangga hanya di berikan pada kelompok perlakuan yang mendapatkan intervensi berupa penyuluhan menggunakan permainan ular tangga. Sedangkan kelompok kontrol tidak mendapatkan intervensi.

Berdasarkan hasil pre-test dan post-test pada penelitian yang telah di lakukan maka di simpulkan bahwa ada pengaruh pemberian penyuluhan makanan jajanan dengan metode permainan ular tangga terhadap pengetahuan anak sekolah di SDN 2 KUTA Kabupaten Lombok Tengah pada anak kelas V menggunaka uji Paired T-test dengan hasil signifikan $\mathrm{p}$ value $=0,00$ atau $\mathrm{p}=(<\mathrm{a} 0,05)$ yang artinya ada pengaruh yang nyata dengan pemberian penyuluhan makanan jajanan dengan metode permainan ular tangga terhadap pengetahuan anak sekolah di SDN 2 KUTA Kabupaten Lombok Tengah.

Berdasarkan hasil antara pre-test dan post-test pada kelompok perlakuan dapat di ketahuai bahwa sebelum di lakukan intervensi tingkat pengetahuan tentang makanan jajanan yakni kategori baik 6 orang $(27,3 \%)$, kategori cukup 13 orang $(59,1 \%)$, kategori kurang 3 orang $(13,6 \%)$, dan hasil tingkat pengetahuan setelah di berikan intervensi berupa penyuluhan makanan jajanan dengan metode permainan ular tangga, yang memiliki tingkat pengetahuan kategori baik 16 orang (72,7\%), kategori cukup 6 orang $(27,3 \%)$.

\section{KESIMPULAN}

Dari hasil penelitian dapat disimpulkan bahwa

Terjadi peningkatan pengetahuan yang awalnya berpengetahuan cukup setelah diberikan intervensi menjadi berpengetahuan baik untuk kelompok perlakuan karena diberikan penyuluhan makanan jajanan dengan metode permainan ular tangga terhadap pengetahuan anak sekolah, sedangkan untuk kelompok kontrol tidak di berikan inervensi sehingga tidak terjadi perubahan atau peningkatan pengetahuan.

Ada pengarunh signifikan dari pemberian penyuluhan makanan jajanan dengan metode permainan ular tangga terhadap pengetahuan anak sekolah di SDN 2 KUTA Kabupaten Lombok Tengah. 


\section{SARAN}

Perlu di jadikan alternatif dalam metode edukasi gizi menggunakan permainan ular tangga dalam pembelajaran karena lebih menyenangkan dan tidak membuat anak - anak menjadi bosan atau mengantuk saat pembelajaran dilaksanakan.

Perlu dilakukan edukasi gizi pada kelompok kontrol untuk menjadi pembanding untuk kelompok perlakuan apakah ada perbedaan pengetahuan pada kelompok yang di berikan edukasi gizi dengan kelompok yang di berikan penyuluhan makanan jajanan dengan metode permainan ular tangga.

Penyuluhan makanan jajanan dengan metode permainan ular tangga perlu di lakukan 2-3x permainan agar siswa kelas 5 SD mampu menguasai materi yang disampaikan.

\section{DAFTAR PUSTAKA}

Andriani, Merryana dan Wirajatmadi, Bambang. 2012. Pengatur gizi masyarakat. Jakarta: Kencana prenada media group.

Judrwanto, Widodo, 2008. Prilaku makan anak sekolah (http://gizi.depkes.go.id/wpcontent/uploads/2012/05/prilaku-makan-anak-sekolah.pdf) diakses pada 25 November 2012.

Maisyaroh, Lis. 2014. “Penerapan metode permainan ular tangga (snakes ledder) untuk meningkatkan hasil belajar siswa pada mata pelajaran IPS”.

Safriana. (2012). Perilaku Memilih Makanan Jajanan Pada Siswa Sekolah Dasar di SDN Garot Kecamatan Darul Imarah Kabupaten Aceh Besar. Tersedia dari : URL : http//www.lib.ui.ac.id [Diakes 12 November 2014]

Sutardji.,M. Azina. 2007. Tingkat Konsumsi Energi dan Konsumsi Protein serta Hubungannya dengan status gizi anak asuh usia 10 - 18 Tahun (Studi pada Penyelenggaraan makanan di Panti Asuhan pamardi putra Kabupaten Demak). Jurnal Kemas, 2(2): 168-173

Wawan dan Dewi. 2010. Teori dan pengukuran pengetahuan, sikap, dan perilaku manusia. Yogyakarta : nuha medika 